\title{
Endocrine disorders and coeliac disease
}

\section{Zaburzenia endokrynologiczne w celiakii}

\author{
Ewa Waszczuk, Julia Jawny \\ Department of Gastroenterology and Hepatology, Medical University, Wrocław, Poland
}

Przegląd Gastroenterologiczny 2011; 6 (4): 209-212

DOI: $10.5114 / p g .2011 .24302$

Key words: coeliac disease (CD), endocrine diseases, autoimmune insulin-dependent diabetes mellitus (AIDDM), autoimmune thyroiditis.

Słowa kluczowe: choroba trzewna, zaburzenia endokrynologiczne, cukrzyca insulinozależna, autoimmunologiczne zapalenie tarczycy.

Address for correspondence: Ewa Waszczuk MD, PhD, Department of Gastroenterology and Hepatology, Medical University of Wroclaw, 213 Borowska, 50-556 Wroclaw, Poland, phone: +48 7173321 20, e-mail: gastro@gastro.am.wroc.pl

\begin{abstract}
Coeliac disease (coeliac sprue, gluten-related enteropathy) is both digestive intolerance and an autoimmune disorder. It is a multifactorial disorder in which genetic, immune, environmental and metabolic factors seem to be most important in its pathogenesis. Because of the diversity of clinical symptoms and more frequent occurrence of this disease than was previously assumed, coeliac disease should be taken into consideration in general practice and specialty clinics (especially endocrinology). The aim of this review article is to present and discuss the associated endocrine disorders that are often the first symptoms of coeliac disease or can suggest its coexistence. Therefore, fast diagnosis and introduction of a glutenfree diet can completely withdraw some of the endocrine disorders, support their treatment and prevent the development of severe complications.
\end{abstract}

\section{Introduction}

Coeliac disease (CD) is a permanent food intolerance, which is characterized by: 1) a defined trigger, gluten (protein generic name for the popular cereals: wheat, rye, barley and oats), 2) the presence of HLA haplotype DQ2 or DQ8, and 3) autoantibodies to the enzyme tissue transglutaminase (tTG).

In genetically predisposed individuals there is an autoimmune reaction in the mucosa of the small intestine under the influence of gluten. This causes the activation of T cells, which leads to a cascade of intracellular reactions, damaging intestinal epithelium and causing various degrees of villous atrophy (Marsh or Schmerling scale). At the same time, the deaminated gluten molecule being a potent antigen induces the pro-

\section{Streszczenie}

Choroba trzewna (coeliac disease - CD) to zapalna enteropatia jelita cienkiego. Objawy schorzenia pojawiają się u osób predysponowanych genetyczne, jednak ważną rolę odgrywają również czynniki immunologiczne, środowiskowe i metaboliczne. Ze względu na częste występowanie i różne postaci kliniczne CD powinno się brać pod uwagę możliwość jej występowania w ośrodkach podstawowej i specjalistycznej opieki zdrowotnej, zwłaszcza endokrynologicznych. Autorzy pracy zwracają uwagę na schorzenia endokrynologiczne, które częściej wspótistnieją z CD, oraz na problem poszukiwania tej choroby wśród pacjentów endokrynologicznych. Ustalenie właściwego rozpoznania i włączenie diety bezglutenowej uchroni pacjentów przed wystąpieniem kolejnych objawów i zapobiegnie ciężkim powikłaniom.

duction of antibodies against tTG, endomysium (EMA), gliadin and reticulum [1].

Due to the broad spectrum of symptoms, CD is currently divided into:

- classic (overt symptoms),

- atypical (subtle symptoms),

- silent (asymptomatic),

- latent,

- refractory [2].

The classic form is most common in children who eat gluten until the $4^{\text {th }}$ year of their life and present the characteristic gastrointestinal symptoms. The clinical picture is dominated by steatorrhoea, abdominal pain, bloating, hypoproteinaemia, anaemia and growth deficiency. The introduction of a gluten-free diet (GFD) 
leads to rapid recovery and a levelling out of all the deficiencies, which are the consequences of malabsorption.

Occurrence of coeliac disease, according to a recent study, is estimated to be more common than had been previously thought, and it ranges from $0.7 \%$ to $3 \%$, but in the one case of classic type accounts for 3-7 cases of latent forms [3]. In recent years, a marked increase in the detection of CD has been noted in adults and people over 60 years of age. It is often asymptomatic or manifests poor symptoms, in which the main complaints are non-specific deficiency disorders or autoimmune diseases [4]. Patients are usually directed first to different medical specialists: dermatologists, endocrinologists, gynaecologists, orthopaedists and neurologists. Duhring's disease (skin sores) is the best-known parenteral disorder associated with CD and closely related to it. Recurrent aphthous ulcerations of the mouth and defects of the tooth enamel, neurological disorders, anaemia, osteoporosis, IgA deficiency, primary biliary cirrhosis, autoimmune hepatitis and thyroiditis, type 1 diabetes mellitus, Addison's disease, reproductive disorders, and Sjögren's syndrome are conditions that may be the only manifestation of coeliac sprue [5].

\section{Diagnostics}

The gold standard diagnosis of gluten enteropathy is a histopathological examination of the duodenum. A positive result is obtained if villous atrophy and hyperplasia of intestinal crypts are found. Simultaneously, the levels of antibodies against tissue transglutaminase (TGA), EMA, and gliadin (AGA) have to be marked. It is obligatory to estimate the level of IgA since deficiency of this protein fraction makes the result falsely negative [6].

\section{Type 1 insulin-dependent diabetes mellitus and coeliac disease}

For many years an increased incidence of $C D$ in patients diagnosed with type 1 diabetes mellitus has been observed. Abundant surveys have shown that the autoimmune insulin-dependent diabetes (AIDDM) concomitant CD may reach $1.1-7.8 \%$, depending on diagnostic methods and the patient's age [7]. The common genetic background of these disorders, namely, the presence of HLA DR3 and B8 alleles, frequently causes the diseases to coexist. The clinical picture, in such cases, is not very characteristic and it is often confused with the complications of diabetes. Diarrhoea and villous atrophy can be a consequence of autonomic nervous system enteropathy or exocrine pancreatic insufficiency. Patients with untreated CD and AIDDM had more episodes of symptomatic hypoglycaemia, and moreover, glucose level was more difficult to regulate [8]. Gluten causes formation of antibodies against pancreatic islet cells in these patients, which tend to decline on a GFD [9]. It was proven that the earlier detection of CD and introduction of GFD lower the risk of developing autoimmune pancreatic disorders [10]. However, the appearance of CD before the symptoms of diabetes often results in severe course of both diseases, as well as in the case of other autoimmune disorders coexistence [11]. Therefore, screening tests performed once a year for gluten-related enteropathy are suggested for patients with AIDDM. In contrast, there is no evidence that the risk of $C D$ in type 2 diabetes mellitus is increased compared to the rest of the population [12].

\section{The coexistence of coeliac disease and dysfunction of the thyroid hormones}

Another large group of endocrine disorders coexisting with $C D$ is autoimmune thyroiditis [13]. The frequency of clinical manifestations (both hypo- and hyperthyroidism) varies from $1.5 \%$ to $6.9 \%$ [2], and is significantly higher in patients over 65 years of age. In case of coexistence of these disorders, it is explained that longer duration of gluten exposure causes a higher risk of autoantibody production [14]. Some authors assess the presence of antithyroid antibodies in patients with CD to be $11-15 \%$. Unfortunately, there are sparse data concerning this topic, because a lot of cases of non-tropical sprue are not diagnosed due to similarity of symptoms in thyroid disorders. It is rational to differentiate these two disease entities, although it is important to consider the possibility of their coexistence [15]. Likewise, treatment with levothyroxine, which does not give the expected therapeutic results, should prompt a doctor to look for causes of malabsorption. The diagnosis of CD and the accompanying introduction of a GFD improve the absorption as well as the effectiveness of treatment with thyroid hormone [16].

\section{Autoimmune Addison's disease and coeliac disease}

Primary adrenal insufficiency is caused by destruction of the adrenal cortex due to formation of adrenal cortex antibodies (ACA) or $21-\mathrm{OH}$ antibodies. Autoimmune polyendocrine syndrome (APS) often develops in the course of this disease. Coeliac disease is accompanied by autoimmune Addison's disease (AAD) at a frequency of $1.2-8 \%$. Although it has been proven that early detection of CD and the introduction of GFD could delay or prevent the symptoms of AIDDM or thyroiditis, there is no similar impact on the development of AAD after elimination of gluten. At the same time, it is worth remembering that Addison's disease occurs with concomitant deficiency of IgA, which may hinder the detection of antibodies against tissue transglutaminase, nec- 
essary for the diagnosis of CD [17]. Since an increased incidence of ventricular disease in patients with $A A D$ has been noticed, screening tests are recommended [18].

\section{Osteoporosis and osteomalacia}

The occurrence of osteoporosis and osteomalacia in patients with CD was noted and described as early as 1953. It happens that osteomalacia and osteoporosis are the first and the only symptoms of the latent form of CD [19]. The main reason for these disorders is a deficiency of calcium, primarily due to villous atrophy, and secondarily due to vitamin D deficiency, the latter being essential for calcium absorption. The obvious consequence of low levels of calcium in the body is the pathological stimulation of the parathyroid glands and appearance of clinical symptoms of secondary hyperparathyroidism. Regardless of what was mentioned above, the inflammatory process observed in the disease and the activation of pro-inflammatory cytokines stimulate osteoclasts. This leads to a decrease of bone mineral density (BMD) and causes osteopenia [20]. However, in patients with $C D$ only a slight increase of the risk of bone fractures can be observed; therefore, densitometry should be undertaken in patients with additional risk factors (women with primary amenorrhea or early menopause) [21]. The introduction of a GFD and supplementation with calcium and vitamin D compensate calcium and phosphate levels, although not all patients improve bone mineral density. If gluten was eliminated in childhood, BMD is normal. Thanks to the diet, patients with CD diagnosed in adulthood can improve bone density but very rarely do they achieve normalization [20].

\section{Growth disorders in children with coeliac disease}

Growth deficit and bone age retardation are common symptoms of CD in children in its classical form with malabsorption. This is caused by the fact that the building molecules and macro- as well as microelements are not absorbed by the body. If symptoms concern the gastrointestinal tract, a suspected diagnosis appears to be simple. However, many cases of children and adults with the only sign of the silent form of $C D$, which is impaired growth, have been described. It is because of possible resistance to growth hormone $(\mathrm{GH})$, manifested by a normal or elevated level of GH and low levels of insulin-like growth factor IGF1 in serum. The elimination of gluten from the diet is the only way to achieve the proper physical development [22]. In rare cases, the diet is not effective. This can be explained by the coexistence of coeliac disease, idiopathic growth hormone deficiency (GHD) and pituitary antibodies (APAs), which are components of autoimmune polyendocrine syndromes (APS 1 and APS 2) [23]. In addition, the exposure time to gluten is an important factor, as well. The later the diet is introduced, the greater the risk of developing subsequent immunological disorders [24].

Neglected CD is a separate problem, in which a patient with already diagnosed enteropathy does not follow the diet. In addition to growth disorders, the risk of malignant complications, such as lymphoma or adenocarcinoma, increases [25].

\section{Reproductive disorders in the course of coeliac disease}

Another broad issue of endocrine comorbidities in $\mathrm{CD}$ is abnormal puberty, fertility, and pregnancy term. Coeliac disease is diagnosed in $4-8 \%$ of women with unexplained infertility. In addition, the delayed appearance of menarche or its total absence and early menopause in patients with CD shortens the reproductive period [26]. Moreover, these women often suffer from recurrent miscarriages and obstetric complications such as intrauterine growth retardation or low birth weight infants or have their pregnancy terminated by a caesarean section [27]. The causes of these disorders are mostly zinc, selenium, iron and folic acid deficiencies, which have a significant influence on the proper secretion of hormones and the normal growth of the fetus [28].

In men who suffer from CD androgen resistance, hyperprolactinaemia and elevated follicle-stimulating hormone have been observed. These disorders may result in impairment of libido and impotence. In addition, deficiency of zinc, selenium and vitamin A seriously interferes with the spermatogenesis process, which affects semen quality and leads to infertility [26, 28].

Introduction of a GFD eliminates these disturbances and allows patients to become pregnant and have an uneventful term [29].

\section{Summary}

Patients with atypical or asymptomatic CD rarely go first to a gastroenterologist. This is the reason $C D$ is diagnosed too late. Endocrinologists should consider the possibility of CD in their patients and effectively diagnose this disorder. The autoimmune nature of the disease causes it to occur more frequently in patients with insulin-dependent diabetes, thyroiditis and autoimmune polyendocrine syndromes (APS 1 and 2). Some studies indicate a higher incidence of $C D$ in AAD. Patients with primary infertility and amenorrhea should be taken into consideration in $C D$ diagnosis. Due to malabsorption in $\mathrm{CD}$, growth deficiency and impaired BMD are common conditions. 
The principal and only treatment for CD is following a GFD, which involves the absolute elimination of gluten-containing foods from the diet. It is estimated that the GFD alone results in regression of the pathological changes attributable to CD in as many as $85 \%$ of patients. Following the diet ensures both physical and mental well-being and prevents potential complications such as osteoporosis, neuropathy, retinopathy, and malignant tumours (non-Hodgkin lymphoma). Moreover, it is important to treat the complementary deficiencies: calcium, magnesium, iron, zinc, selenium, folic acid, and vitamins $A, D, E, K$ and $B_{12}$. Only in rare cases is pharmacotherapy necessary (steroids or immunosuppressants).

\section{References}

1. Hourigan CS. The molecular basis of celiac disease. Clin Exp Med 2006; 6: 53-9.

2. Rostom A, Murray JA, Kagnoff MF. American Gastroenterological Association (AGA) Institute Technical review on the diagnosis and management of celiac disease. Gastroenterology 2006; 131: 1981-2002.

3. Iwańczak B, Matusiewicz K. Current knowledge on epidemiology and pathomechanism of celiac disease. Gastroenterol Pol 2007; 14: 45-9.

4. Holmes GKT. Potential and latent coeliac disease. Eur J Gastroenterol Hepatol 2001; 13: 1057-60.

5. Briani C, Samaroo D, Alaedini A. Celiac disease: from gluten to autoimmunity. Autoim Rev 2008; 7: 644-50.

6. Rostom A, Dube C, Cranney A, et al. Celiac disease. Evid Rep Technol Assess 2004; 104 :1-6.

7. De Vitis I, Ghirlanda G, Gasbarrini G. Prevalence of coeliac disease in type I diabetes: a multicentre study. Acta Paediatr Suppl 1996; 412: 56-7.

8. Shanahan F, McKenna R, McCarthy CF, et al. Coeliac disease and diabetes mellitus: a study of 24 patients with HLA typing. Q J Med 1982; 51: 329-35.

9. Ventura A, Magazzu G, Greco L. Duration of exposure to gluten and risk for autoimmune disorders in patients with celiac disease. Gastroenterology 1999; 117: 297-303.

10. Ventura A, Greco L. Duration of exposure to gluten and risk for autoimmune disorders in patients with celiac disease. SIGEP Study Group for Autoimmune Disorders in Celiac Disease. Gastroenterology 1999; 117: 297-303.

11. Valerio G, Maiuri L, Troncone R. Severe clinical onset of diabetes and increased prevalence of other autoimmune diseases in children with celiac disease diagnosed before diabetes mellitus. Diabetologia 2002; 45: 1719-22.

12. Sjoeberg K, Eriksson KF, Brendberg A, et al. Screening for coeliac disease in adult insulin-dependent diabetes mellitus. J Intern Med 1998; 243: 133-40.

13. Collin P, Salmi J, Hallstrom O, et al. Autoimmune thyroid disorders and celiac disease. Eur J Endocrinol 1994; 130: 137-40.
14. Ventura A, Neri E, Ughi C, et al. Gluten-dependent diabetesrelated and thyroid-related autoantibodies in patients with celiac disease. J Pediatr 2000; 137: 263-5.

15. Counsell CE, Taha A, Ruddell WSJ. Coeliac disease and autoimmune thyroid disease. Gut 1994; 35: 844-6.

16. Waszczuk E, Ciupek M, Paradowski L. Intestinal malabsorption causes of failure replacement therapy in hypothyroidism. Gastroenterol Pol 2009; 16: 395-8.

17. Betterle C, Lazzarotto F, Spadaccino AC, et al. Celiac disease in North Italian patients with autoimmune Addison's disease. Eur J Endocrinol 2006; 154: 275-9.

18. Myhre A, Aarsetøy E, Undlien DN, et al. High frequency of coeliac disease among patients with autoimmune adrenocortical failure. Scand I Gastroenterol 2003; 38: 511-5.

19. Harzy T, Benbouazza K, Amine B, et al. An unusual case of osteomalacia as the presenting featureof celiac disease. Rheumatol Int 2005; 26: 90-1.

20. Corazza GR, Di Stefano M, Maurino E, et al. Bones in celiac disease: diagnosis and treatment. Best Pract Res Clin Gastroenterol 2005; 19: 453-65.

21. Compston J. Is fracture risk increased in patients with coeliac disease? Gut 2003; 52: 459-60.

22. Nemet D, Raz A, Zifman E, et al. Short stature, celiac disease and growth hormone deficiency. J Pediatr Endocrinol Metab 2009; 22: 979-83.

23. Fasano A, Counts D. Commentary on "Anti-pituary antibodies in children with newly diagnosed celiac disease: a novel finding contributing to linear growth". Am J Gastroenterol 2010; 105: 697-8.

24. Iughetti L, De Bellis A, Predieri B, et al. Growth hormone impaired secretion and antipituitary antibodies in patients with coeliac disease and poor catch-up growth after a long glutenfree diet period: a causal association? Eur J Pediatr 2006; 165: 897-903.

25. Brousse N, Meijer JWR. Malignant complications of celiac disease. Best Pract Res Clin Gastroenterol 2005; 19: 401-12.

26. Karagiannis A, Harsoulis F. Gonadal dysfunction in systemic diseases. Eur J Endocrinol 2005; 152: 501-13.

27. Martinelli P, Troncone R, Paparo F, et al. Coeliac disease and unfavourable outcome of pregnancy. Gut 2000; 46: 332-5.

28. Rostami K, Steegers EAP, Wong WY, et al. Coeliac disease and reproductive disorders: a neglected association. Eur J Obstet Gynecol Reprod Biol 2001; 96: 146-9.

29. Rajput R, Chatterjee S. Primary infertility as a rare presentation of celiac disease. Fertil Steril 2010; 94: 2771.e5-7. 